\title{
Kultur Campuran dan Faktor Lingkungan Mikroorganisme yang Berperan dalam Fermentasi "Tea-Cider"
}

\author{
Pingkan Aditiwati ${ }^{1} \&$ Kusnadi $^{2}$ \\ ${ }^{1}$ Departemen Biologi - FMIPA Institut Teknologi Bandung \\ ${ }^{2}$ Jurusan Biologi - FMIPA Universitas Pendidikan Indonesia Bandung
}

\begin{abstract}
Abstrak. Teh merupakan hasil pertanian yang mengandung senyawa berkhasiat, terutama dalam bidang kesehatan. Penelitian mengenai fermentasi "Tea-cider" telah dilakukan dengan metode kultur curah. Tujuan penelitian adalah untuk mengetahui kultur campuran mikroorganisme yang berperan aktif dalam proses tersebut, menentukan kondisi optimum fermentasi dan menguji kemampuan produk fermentasi dalam menghambat pertumbuhan bakteri patogen. Penelitian dilakukan dalam dua tahap, pertama isolasi mikroorganisme yang terdapat dalam bibit "Tea-cider" dan kedua, tahap produksi "Tea-cider" dengan menggunakan inokulum berupa kultur campuran isolat murni hasil isolasi dan cairan "Teacider". Optimasi proses fermentasi dilakukan terhadap perbandingan inokulum, yaitu antara kultur campuran isolat murni hasil isolasi pada variasi perbandingan jumlah sel awal B : K1 : K2 = $1: 1: 1,3: 1: 1$ dan $5: 1: 1$, dengan inokulum pada variasi $5 \%, 10 \%$, dan $15 \%(\mathrm{v} / \mathrm{v})$. Optimasi suhu dengan variasi $25^{\circ} \mathrm{C}, 28^{\circ} \mathrm{C}$, $30^{\circ} \mathrm{C}$, dan $35^{\circ} \mathrm{C}, \mathrm{pH}$ awal medium dengan variasi 4,5 , dan 6 , kadar gula awal dengan variasi $5 \%, 10 \%$, dan $15 \%(\mathrm{~b} / \mathrm{v})$. Analisis terhadap $\mathrm{pH}$, kadar asam, kadar gula, dan kadar alkohol dilakukan selama 14 hari fermentasi dengan interval 48 jam. Selanjutnya dilakukan uji organoleptik terhadap produk fermentasi serta uji antimikroba dengan metode difusi agar. Hasil penelitian menunjukkan bahwa kultur campuran mikroorganisme yang berperan aktif dalam proses fermentasi "Tea-cider" terdiri dari dua jenis khamir, yaitu Schizosaccharomyces pombe (K1) dan Brettanomyces sp (K2) dan satu jenis bakteri asam asetat, yaitu Acetobacter xylinum (B). Kondisi optimum untuk fermentasi "Tea-cider" diperoleh dengan inokulum kultur campuran isolat murni hasil isolasi dengan perbandingan $\mathrm{B}: \mathrm{K} 1: \mathrm{K} 2$ adalah $5: 1: 1$ dan inokulum $10 \%$ $(\mathrm{v} / \mathrm{v})$, suhu inkubasi optimum $30^{\circ} \mathrm{C}, \mathrm{pH}$ awal medium 5 , dan kadar gula awal $10 \%(\mathrm{~b} / \mathrm{v})$. "Tea-cider" mampu menghambat pertumbuhan beberapa bakteri patogen, yaitu Staphylococcus aureus, Pseudomonas aeruginosa, dan Escherichia coli. Produk fermentasi "Tea-cider" juga memiliki cita rasa yang disukai.
\end{abstract}

Abstract. Tea is agricultural product containing beneficial substances, especially used for human health. The study of "Tea-cider" fermentation has been conducted using batch culture method. The purposes of the study were to observe mixed microbial culture which were actively involved in the process of "Tea-cider" fermentation, to determine the optimum fermentation conditions, as well as to evaluate the inhibition effect of the product against pathogenic 
bacteria. The study was carried out in two steps. Firstly, the isolation of microorganisms from "Tea-cider"; secondly producing "Tea-cider" using mixed microbial culture isolated from "Tea-cider" and "Tea-cider" itself as inoculum. Type and concentration of inoculum were optimized for the fermentation process. Mixed of the pure culture of isolated microorganisms with variation of initial cell at ratio $\mathrm{B}: \mathrm{K} 1: \mathrm{K} 2=1: 1: 1,3: 1: 1$ and $5: 1: 1$ while the variation of inoculum were $5 \%, 10 \%$, and $15 \%(\mathrm{v} / \mathrm{v})$. Optimization in temperature, $\mathrm{pH}$ and sugar concentration at the variation of temperature $25^{\circ} \mathrm{C}, 28^{\circ} \mathrm{C}, 30^{\circ} \mathrm{C}$, and $35^{\circ} \mathrm{C}$, $\mathrm{pH}$ of 4,5 , and 6 , and sugar concentration $5 \%, 10 \%$, and $15 \%(\mathrm{w} / \mathrm{v})$ respectively. The $\mathrm{pH}$, acid concentration, reducing sugar concentration and alcohol concentration were analized at 48 hours interval during 14 days fermentation. The product was tested for antimicrobial effect using agar diffusion method and for organoleptic. The result showed that mixed microbial culture which were actively involved in "Tea-cider" fermentation were yeast Schizosaccharomyces pombe (K1) dan Brettanomyces sp (K2), and a species af aceticacid Acetobacter xylinum (B). The optimum condition of "Tea-cider" fermentation were as follows, the ratio of $\mathrm{B}: \mathrm{K} 1: \mathrm{K} 2$ optimum mixed culture inoculum at $5: 1: 1$ and $10 \%(\mathrm{v} / \mathrm{v})$ for the inoculum. The incubation temperature was $30^{\circ} \mathrm{C}$, the medium initial $\mathrm{pH}$ was 5 and the intial sugar concentration was $10 \%(\mathrm{w} / \mathrm{v})$. The "Teacider" product was able to inhibit the growth of some pathogenic bacteria such as Staphylococcus aureus, Pseudomonas aeruginosa and Escherichia coli and had a good preferred taste.

\section{$1 \quad$ Pendahuluan}

Secara umum fermentasi merupakan perubahan kimiawi dari senyawa-senyawa organik oleh enzim yang dihasilkan oleh mikroorganisme ${ }^{(10)}$. Mikroorganisme yang berperan dalam proses fermentasi ini terutama dari golongan khamir (yeast), kapang (fungi) dan bakteri. Fermentasi berbagai bahan makanan dan minuman dapat melibatkan satu macam atau beberapa mikroorganisme yang bekerja secara simbiotik ${ }^{(17)}$.

Daun teh merupakan produk pertanian yang dihasilkan hampir disemua negara, terutama di negara-negara tropis dan sub-tropis. Hasil penelitian menunjukkan bahwa daun teh mengandung senyawa-senyawa yang memiliki manfaat dan khasiat yang luas. Di samping dapat meningkatkan proses metabolisme, teh berkhasiat sebagai anti kanker, antibakteri, antioksidan, menurunkan tekanan darah, dan menurunkan kandungan kolesterol dalam darah salah satu hal yang belum banyak diteliti adalah kemampuan anti bakterinya. ${ }^{(17)}$

"Tea-cider" atau yang lebih dikenal dengan nama "Kombucha", merupakan produk minuman tradisional hasil fermentasi larutan teh dan gula yang memiliki cita rasa dan aroma yang khas, yaitu rasa asam-manis, mengandung berbagai vitamin dan mineral serta asam-asam organik yang berasal dari daun teh setelah difermentasi ${ }^{(12,20)}$. "Tea-cider" merupakan hasil fermentasi kultur khamir dan 
bakteri asam asetat. Proses fermentasi "Tea-cider" dipengaruhi oleh beberapa faktor lingkungan, seperti jumlah inokulum (bibit), suhu inkubasi, $\mathrm{pH}$ dan kadar sukrosa awal ${ }^{(12,13)}$.

Penelitian mengenai fermentasi "Tea-cider" dilakukan dengan tujuan untuk mengisolasi kultur campuran mikroorganisme yang berperan aktif dalam proses tersebut membuat Tea-cider dengan mikroorganisme hasil isolasi, menentukan kondisi optimum fermentasi, dan menguji kemampuan produk fermentasi dalam menghambat pertumbuhan bakteri patogen (kemampuan anti bakteri).

\section{Bahan dan Metode}

Bahan yang digunakan sebagai medium dalam fermentasi "Tea-cider" adalah gula pasir dan teh hitam ("black tea") dari jenis yang sama serta bibit "Teacider".

Media yang digunakan dalam isolasi dan penghitungan total mikroorganisme yang terdapat dalam "Tea-cider" adalah "Nutrient Agar" (NA) yang ditambah asam nitrat 1,5\% dan medium selektif Acetobacter xylinum untuk bakteri, serta "Potato Dextrose Agar" (PDA) dan "Yeast Extract Pepton Dextrose Agar" (YEPDA) untuk khamir ${ }^{(1)}$. Penentuan media didasarkan pada hasil uji pendahuluan yang menunjukkan adanya pertumbuhan bakteri asam asetat, yaitu Acetobacter xylinum dan khamir dalam bibit "Tea-cider". Bahan-bahan lain yang digunakan untuk isolasi dan identifikasi isolat meliputi reagen perwarnaan sederhana dan pewarnaan Gram serta reagen untuk uji aktivitas biokimia.

Metode penelitian meliputi dua tahap, pertama adalah isolasi dan identifikasi mikroorganisme dari "Tea-cider", kedua adalah produksi "Tea-cider" dengan menggunakan kultur campuran isolat murni hasil isolasi dan dari cairan "Teacider" sebagai inokulum. Isolasi mikroorganisme dilakukan dari cairan "Teacider"dengan menggunakan metode "pour plate"(6). Isolat yang telah murni digunakan sebagai kultur induk.

Identifikasi isolat bakteri dan khamir dilakukan melalui pengamatan morfologi meliputi pengamatan bentuk dan warna koloni, sedangkan pengamatan mikroskopis, bentuk sel melalui pewarnaan Gram untuk bakteri, dan pewarnaan sederhana untuk khamir. Selanjutnya dilakukan uji aktivitas biokimia untuk isolat bakteri dan khamir. Prosedur identifikasi mengacu pada Buchanan (1974) untuk bakteri maupun khamir $^{(4,19)}$.

Langkah selanjutnya adalah produksi "Tea-cider" yang didahului dengan optimasi. Optimasi inokulum pada kultur campuran isolat murni hasil isolasi menggunakan variasi perbandingan jumlah sel awal isolat bakteri berbanding 
isolat khamir (B : K1 : K2) $: 1: 1: 1 ; 3: 1: 1 ; 5: 1: 1$ dan inokulum dengan variasi jumlah inokulum $5 \%, 10 \%$, dan $15 \%(\mathrm{v} / \mathrm{v})$, variasi kadar sukrosa awal $5 \%, 10 \%$, dan $15 \%(\mathrm{~b} / \mathrm{v})$, variasi $\mathrm{pH}$ awal medium fermentasi 4,5 , dan 6 serta variasi suhu inkubasi $25^{\circ} \mathrm{C}, 28^{\circ} \mathrm{C}, 30^{\circ} \mathrm{C}$, dan $35^{\circ} \mathrm{C}$. Perlakuan yang memberikan kenaikan kadar asam asetat tinggi digunakan untuk perlakuan dalam produksi "Tea-cider". Fermentasi dilakukan selama 14 hari, pada interval 48 jam dilakukan pengukuran kadar asam asetat, $\mathrm{pH}$, gula reduksi dan kadar alkohol. Penentuan kadar asam asetat dilakukan dengan metode volumetri atau titrasi ${ }^{(6,7)}$. Pengukuran $\mathrm{pH}$ selama proses fermentasi dilakukan dengan menggunakan $\mathrm{pH}$ meter elektrik SIBATA pH-831 dengan buffer $\mathrm{pH}$ 7. Penentuan kadar alkohol dilakukan dengan menggunakan metode Specific Gravity Official Final Action $^{(18)}$ dan gula reduksi ditentukan dengan metode somogyi-Nelson ${ }^{(8)}$.

Pola pertumbuhan kultur campuran mikroorganisme dalam kultur campuran dibuat untuk mengetahui perubahan kultur campuran mikroorganisme yang berperan aktif dalam fermentasi "Tea-cider", yaitu dengan mengisolasi mikroorganisme produk "Tea-cider" yang optimum dari hari ke 0 sampai hari ke 14 dalam interval 48 jam dengan metode hitungan cawan ("pour plate") ${ }^{(6)}$. Selanjutnya dilakukan uji aktivitas antimikroba untuk mengetahui kemampuan produk fermentasi "Tea-cider" dalam menghambat pertumbuhan mikroba patogen. Uji antimikroba dilakukan dengan metode difusi agar ("agar diffucion") ${ }^{(9)}$. Uji dilakukan terhadap beberapa bakteri patogen terhadap manusia yang bisa menimbulkan penyakit, yaitu Escherichia coli, Pseudomonas aeruginosa, dan Staphylococcus aureus ${ }^{(5)}$. Tahap selanjutnya dilakukan uji organoleptik terhadap rasa, aroma, dan warna dari produk "Tea-cider" mulai dari hari ke 6 sampai hari ke 14 selama interval dua hari dengan metode "Rating scale test". Metode ini dimaksudkan untuk menilai produk fermentasi yang paling disenangi panelis ${ }^{(25)}$.

\section{Hasil dan Pembahasan}

\subsection{Isolat dan Identifikasi Mikroorganisme Yang Berperan Aktif dalam Fermentasi "Tea-cider"}

Isolat mikroorganisme yang berhasil di isolasi dari "Tea-cider" dalam bentuk kultur murni terdiri dari dua jenis khamir (K1 dan K2) dan satu jenis bakteri (B). Setelah dilakukan identifikasi baik terhadap karakteristik morfologi sel maupun uji aktivitas biokimia, diketahui bahwa isolat khamir K1 adalah Schizosacccharomyces pombe dan $\mathrm{K} 2$ adalah Brettanomyces sp, sedangkan isolat bakteri adalah Acetobacter xylinum ${ }^{(24)}$. Morfologi sel dari ketiga isolat dapat dilihat pada gambar 1 . 

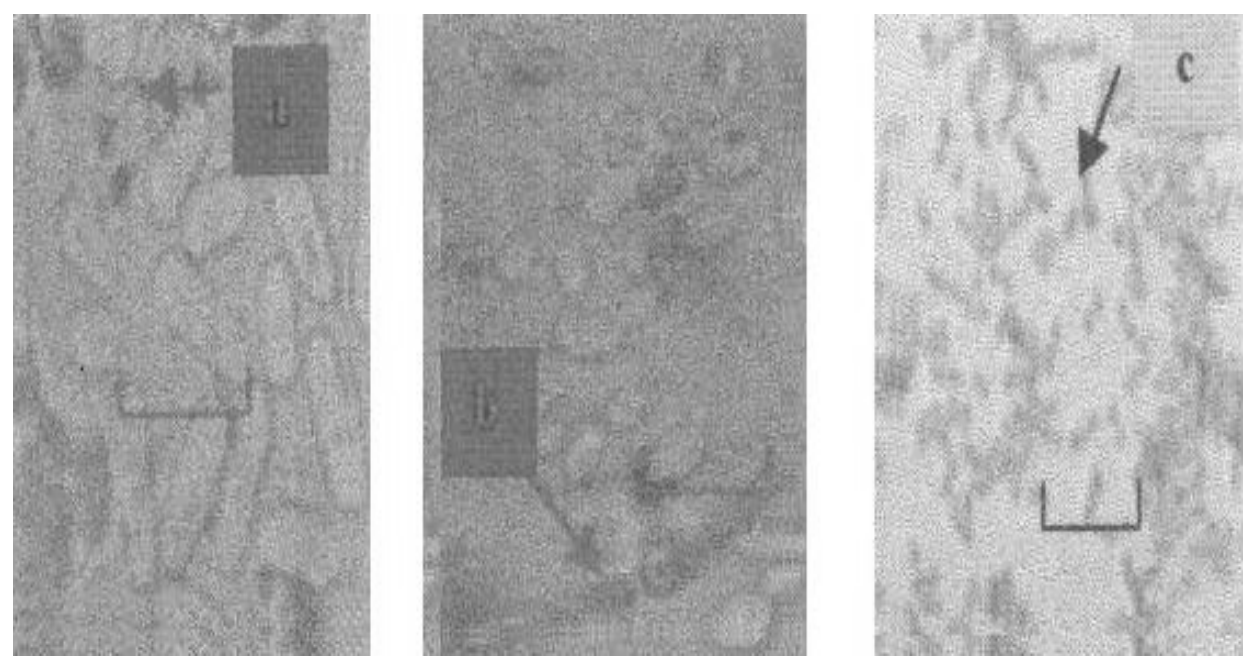

Gambar 1 Isolat khamir (K1 dan K2) dan bakteri (B) hasil isolasi dari cairan "Tea-cider".

\section{Keterangan:}

$\mathrm{K} 1$ = Schizosacccharomyces pombe, $\mathrm{K} 2=$ Brettanomyces $s p$ (pewarnaan biru metilin), B = Acetobacter xylinum (pewarnaan Gram); $\mathrm{a}=$ pembelahan sel $\mathrm{K} 1 ; \mathrm{b}$ $=$ pseudomiselium; $\mathrm{c}=$ bentuk sel $\mathrm{B}$ batang pendek, berpasangan, Skala K1, K2 $=10 \mu \mathrm{m}, \mathrm{B}=5 \mu \mathrm{m}$.

Hasil tersebut menunjukkan bahwa kultur campuran mikroorganisme yang terdapat dalam "Tea-cider" terdiri dari khamir dan bakteri asam asetat, sehingga peranan mikroorganisme tersebut dalam proses fermentasi dapat dibagi menjadi dua kelompok berdasarkan aktivitas metabolisme-nya ${ }^{(15,21)}$. Selama proses fermentasi berlangsung maka khamir (K1 dan K2) akan mengubah gula (sukrosa) dalam medium menjadi alkohol dan senyawa lain yang secara simultan dilanjutkan dengan oksidasi alkohol menjadi asam asetat oleh bakteri Acetobacter xylinum. Khamir akan menghasilkan enzim-enzim seperti invertase, zimase, karboksilase, heksokinase, dehidrogenase, dan bakteri menghasilkan enzim alkohol dehidrogenase ${ }^{(22)}$.

Bakteri Acetobacter xylinum mampu mengoksidasi glukosa menjadi asam glukonat dan asam organik lain pada waktu yang sama. Selain itu dapat mensintesis glukosa menjadi polisakarida atau selulosa berupa serat-serat putih, yang terbentuk secara bertahap dari lapisan tipis pada awal fermentasi hingga mencapai ketebalan sekitar $12 \mathrm{~mm}$ pada akhir fermentasi, kemudian disebut sebagai "nata". 


\subsection{Optimasi Faktor Lingkungan Fermentasi}

\subsubsection{Penentuan Jumlah Inokulum}

Hasil penelitian menunjukkan bahwa jumlah inokulum mempengaruhi produksi asam asetat (gambar 2). Jumlah inokulum optimum dari kultur "starter" untuk produksi "Tea-cider" adalah $10 \%(\mathrm{v} / \mathrm{v})$, dengan menghasilkan asam asetat tertinggi, yaitu sekitar $0,78 \%$. Hal ini disebabkan karena ketersediaan nutrisi sebagai substrat sebanding dengan jumlah mikroorganisme, substrat digunakan untuk pertumbuhan, perbanyakan sel dan produksi asam-asam organik.

Penambahan jumlah inokulum 5\% dan $15 \%$ (v/v) tidak menghasilkan asam asetat sebanyak pada penambahan inokulum $10 \%$. Pada penambahan inokulum $5 \%(\mathrm{v} / \mathrm{v})$, enzim yang dihasilkan oleh mikroorganisme yang berperan aktif dalam fermentasi "Tea-cider" jumlahnya tidak mencukupi untuk mengubah substrat yang ada, sehingga laju pembentukan asam asetat rendah. Laju pembentukan asam asetat dengan penambahan inokulum $15 \%(\mathrm{v} / \mathrm{v})$ juga rendah, hal ini disebabkan karena terjadinya kompetisi antara mikroorganisme dalam memanfaatkan nutrisi (substrat) yang ada. Penurunan laju pembahasan asam asetat disebabkan oleh laju pembentukan produk yang semakin tinggi, sehingga produk yang dihasilkan dapat menghambat reaksi penguraian substrat menjadi produk.

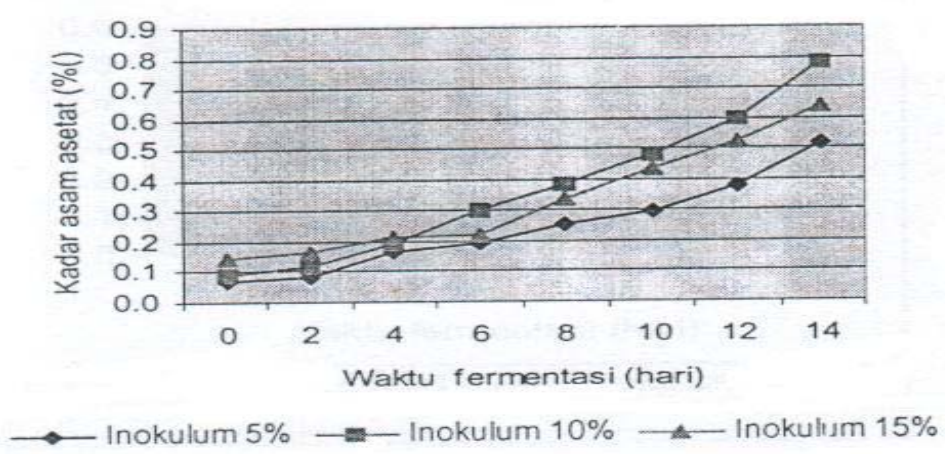

Gambar 2 Hasil produksi asam asetat "Tea-cider dengan variasi inokulum kultur campuran alami ("starter") 5\%,10\% dan 15\% (v/v).

Grafik pada gambar 3 memperlihatkan bahwa laju pembentukan asam asetat paling tinggi diperoleh dari kultur campuran dengan perbandingan jumlah sel awal $(\mathrm{B}: \mathrm{K} 1: \mathrm{K} 2)=5: 1: 1$. Perbandingan ini menghasilkan produksi asam asetat paling tinggi karena pembentukan asam asetat dihasilkan terutama oleh aktivitas bakteri Acetobacter xylinum. Sehingga dengan komposisi jumlah sel awal bakteri Acetobacter xylinum yang lebih banyak maka produksi asam asetat 
pun meningkat. Sedangkan dengan perbandingan jumlah sel awal $1: 1: 1$ dan 3 $: 1: 1$ pembentukan asam asetat rendah. Hal ini terjadi karena laju pertumbuhan khamir lebih dominan karena kondisi fermentasinya lebih mendukung dibandingkan dengan laju pertumbuhan bakteri yang lambat. Kompetisi pertumbuhan ini menyebabkan produk metabolisme khamir, yaitu alkohol lebih tinggi dibandingkan dengan asam asetat ${ }^{(2,3)}$.

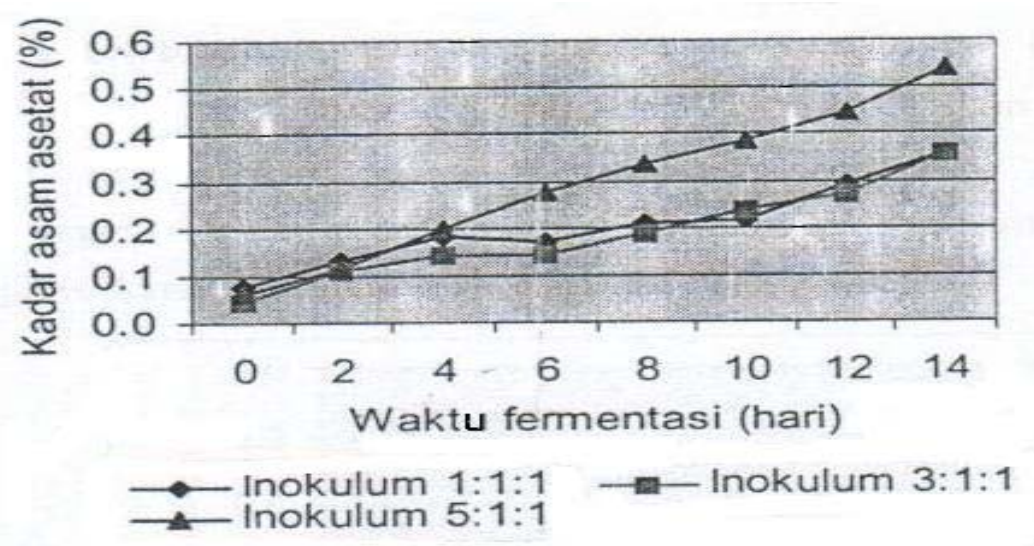

Gambar 3 Hasil produksi asam asetat (\%) “Tea-cider" dengan inokulum kultur campuran isolat hasil isolasi pada variasi perbandingan jumlah sel yang berbeda.

\subsubsection{Penentuan Penambahan Kadar Gula Awal Terbaik}

Hasil penelitian menunjukkan bahwa laju pembentukan asam asetat dipengaruhi oleh konsentrasi sukrosa awal. Penambahan sukrosa awal $10 \%(\mathrm{~b} / \mathrm{v})$ memberikan produksi asam asetat yang tertinggi dibandingkan dengan penambahan sukrosa $5 \%$ dan $15 \%$ yaitu sebesar $0,762 \%$ (gambar 4). Hal ini terjadi karena mikroorganisme menghasilkan enzim yang sebanding dengan jumlah substrat (sukrosa), sehingga laju pembentukan asam asetat tinggi. Penambahan kadar sukrosa $5 \%(\mathrm{~b} / \mathrm{v})$ menyebabkan nutrisi atau substrat yang tersedia dalam medium tidak mencukupi untuk aktivitas metabolisme sel-sel mikroorganisme, sehingga laju pembentukan asam asetat lebih rendah dari kadar sukrosa awal $10 \%$ dan $15 \%(\mathrm{~b} / \mathrm{v})$, sedangkan dengan penambahan kadar sukrosa $15 \%(\mathrm{~b} / \mathrm{v})$ menyebabkan konsentrasi substrat dalam medium berlebih, sehingga diawal produksi asam asetat meningkat dan menyebabkan penghambatan balik terhadap proses enzimatis sehingga dengan jumlah enzim yang dihasilkan produksi asam asetat terhambat. ${ }^{(10,22)}$ 


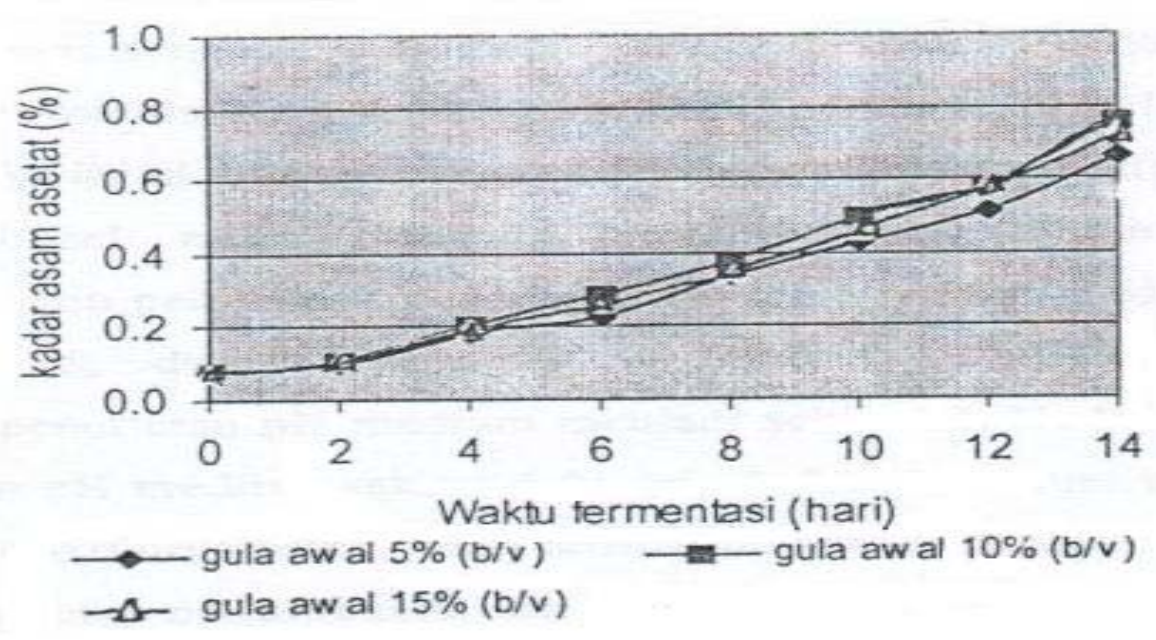

Gambar 4 Hasil produksi asam asetat (\%) "Tea-cider" dengan variasi kadar sukrosa awal 5\%, 10\% dan 15\% (b/v).

\subsubsection{Penentuan pH Awal Medium Fermentasi}

Hasil penelitian menunjukkan $\mathrm{pH}$ awal medium mempengaruhi laju pembentukan asam asetat. $\mathrm{pH}$ awal medium 5 menghasilkan kadar asam asetat yang tertinggi. Hal ini terjadi karena mikroorganisme yang berperan dalam fermentasi "Tea-cider" termasuk mikroorganisme mesofilik, dengan pertumbuhan optimum pada $\mathrm{pH}$ medium antara 4 dan $5^{(4)}$. Setelah penambahan inokulum $\mathrm{pH}$ medium $(5,0)$ menjadi 4,2 , sehingga aktivitas metabolisme sel-sel mikroorganisme dalam memproduksi kadar asam asetat cukup tinggi, yaitu $0,78 \%$.

$\mathrm{pH}$ awal medium 4 tidak menghasilkan asam asetat yang tinggi, karena dengan penambahan inokulum $10 \%(\mathrm{v} / \mathrm{v})$, maka terjadi penurunan $\mathrm{pH}$ awal medium (4) menjadi lebih asam (sekitar $\mathrm{pH} 3,3$ ) sehingga kondisi ini akan mempengaruhi pertumbuhan dan aktivitas metabolisme sel-sel mikroorganisme, terutama selsel khamir. Hal ini mengakibatkan laju pembentukan asam asetat lebih rendah. Pada $\mathrm{pH}$ awal medium 6 terjadi penurunan $\mathrm{pH}$ medium menjadi sekitar 5,01 setelah penambahan inokulum $10 \%$. Kondisi substrat dengan $\mathrm{pH}$ medium ini, belum optimal pertumbuhan mikroorganisme, terutama bagi pertumbuhan dan aktivitas metabolisme bakteri Acetobacter xylinum, sehingga pembentukan asam asetat terhambat. Hal ini terjadi karena untuk aktivitas enzim-enzim yang dihasilkan oleh bakteri Acetobacter xylinum bekerja optimum pada $\mathrm{pH} 4-5^{(4)}$. 


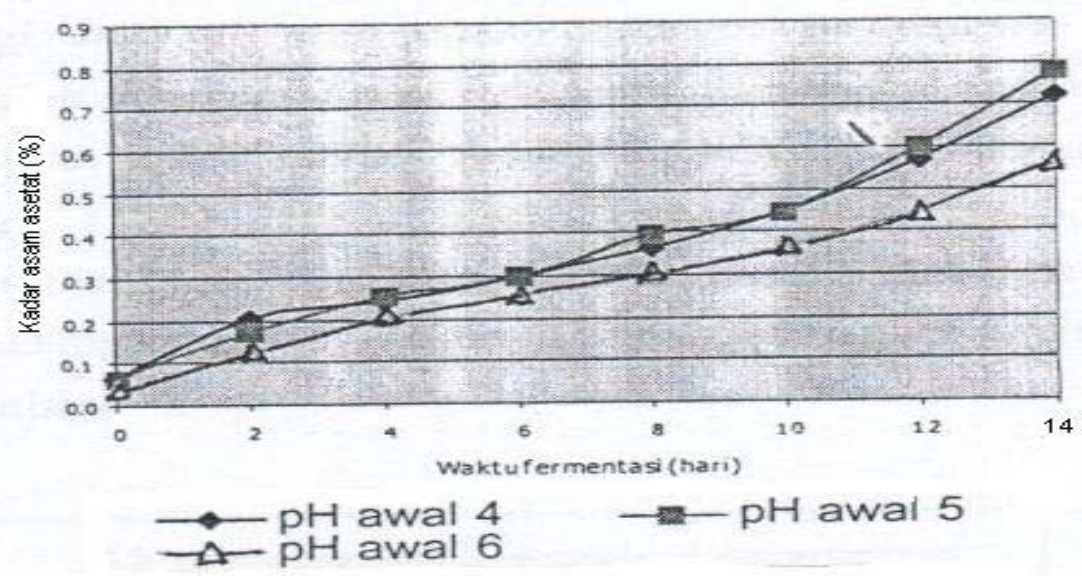

Gambar 5 Hasil produksi asam asetat (\%) “Tea-cider” dengan inokulum kultur campuran alami $10 \%$ pada variasi $\mathrm{pH}$ awal, medium fermentasi 4,5 , dan 6 .

\subsubsection{Penentuan Suhu Fermentasi Terbaik}

Hasil penelitian menunjukkan bahwa suhu inkubasi mempengaruhi laju pembentukan asam asetat. Grafik pada gambar 6 menunjukkan bahwa pembentukan asam asetat pada akhir fermentasi cukup tinggi pada suhu inkubasi antara $28^{\circ} \mathrm{C}$ dan $30^{\circ} \mathrm{C}$ namun rata-rata laju pembentukan asam asetat dalam interval 48 jam, terutama setelah hari ke 2 menunjukkan suhu inkubasi $30^{\circ} \mathrm{C}$ untuk fermentasi "Tea-cider" lebih baik dibandingkan suhu $28^{\circ} \mathrm{C}$. Hal ini disebabkan oleh aktivitas sel mikroorganisme yang terlibat dalam fermentasi "Tea-cider", terutama pertumbuhan dan metabolisme bakteri asam asetat, tumbuh optimal pada suhu $30^{\circ} \mathrm{C}^{(4,25)}$.

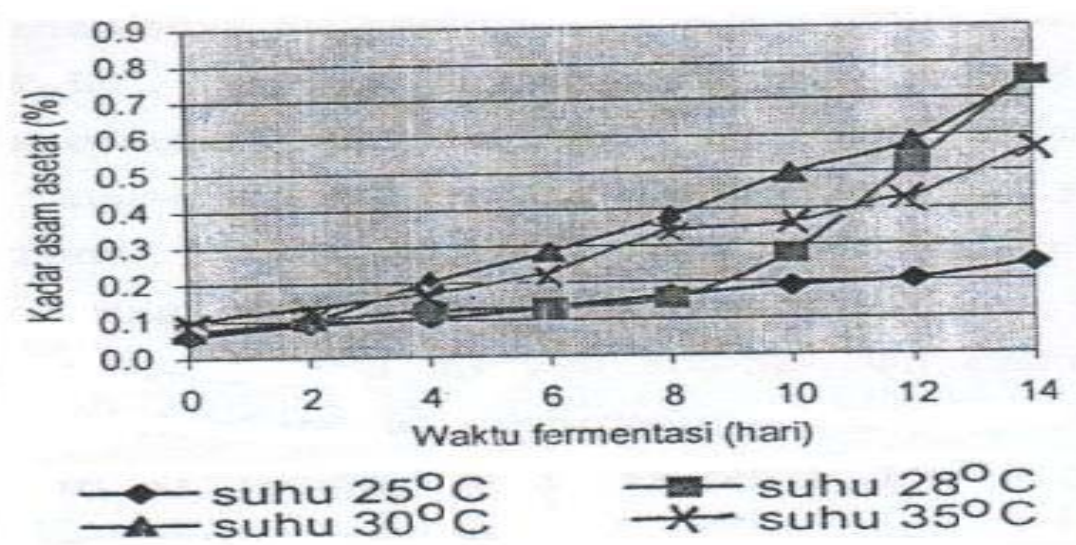

Gambar 6 Hasil produksi asam asetat (\%) “Tea-cider" pada variasi suhu inkubasi $25,28,30$, dan $35^{\circ} \mathrm{C}$. 
Sedangkan pada suhu inkubasi $25^{\circ} \mathrm{C}$ dibutuhkan energi aktivasi yang lebih tinggi untuk kerja enzim, sehingga aktivitas mikroorganisme dalam membentuk asam asetat sangat rendah. Pada suhu inkubasi yang cukup tinggi $35^{\circ} \mathrm{C}$ dapat terjadi inaktivasi enzim, karena diduga sebagian protein-enzim dapat terdenaturasi pada suhu tersebut, sehingga akan mengurangi produksi asam asetat oleh mikroorganisme.

\section{Pola Pertumbuhan Kultur Campuran Mikroorganisme dalam Fermentasi "Tea-cider"}

Hasil menunjukkan bahwa selama proses fermentasi terjadi perubahan jumlah masing-masing jenis mikroorganisme, baik khamir (K1 dan K2) maupun bakteri asam asetat (B) (gambar 7). Hal ini sejalan dengan perubahan pada medium fermentasi karena dihasilkannya produk-produk metabolit sebagai aktivitas metabolisme mikroorganisme yang terlibat dalam fermentasi "Tea-cider". Kondisi ini akan mempengaruhi pertumbuhan dan interaksi mikroorganisme satu dengan lainnya.

Setelah dua hari laju pertumbuhan sari sel-sel khamir meningkat, karena ketersediaan substrat serta $\mathrm{pH}$ medium cocok bagi pertumbuhan sel khamir untuk dapat mengubah glukosa menjadi alkohol dan asam-asam organik. Setelah hari ke 8 terjadi penurunan $\mathrm{pH}$ medium menjadi asam (kurang dari 3), sehingga aktivitas sel-sel khamir terhambat dan jumlah sel-sel khamir menurun.

Pertumbuhan bakteri Acetobacter xylinum meningkat setelah hari ke 2, seiring dengan terbentuknya "nata" dengan ketebalan lebih kurang $1 \mathrm{~mm}$ (hari ke 2) sampai $12 \mathrm{~mm}$ (hari ke 14). Setelah hari ke 2, kondisi substrat (medium fermentasi) sudah cocok bagi pertumbuhan sel-sel bakteri Acetobacter xylinum, karena dihasilkannya metabolit oleh aktivitas sel-sel khamir yang mengubah sukrosa dengan bantuan enzim invertase menjadi glukosa dan fruktosa. Senyawa ini merupakan prekusor bagi pertumbuhan bakteri Acetobacter xylinum $^{(23)}$.

Pola pertumbuhan ketiga mikroorganisme tersebut secara umum menunjukkan adanya hubungan atau simbiosis, terutama dalam hal penyediaan nutrisi dan kondisi substrat bagi masing-masing mikroorganisme. Sel-sel khamir menghasilkan alkohol dan beberapa asam organik sebagai substrat dan prekusor bagi aktivitas sel-sel bakteri. Terbentuknya lapisan "nata" di permukaan cairan yang dihasilkan oleh aktivitas bakteri Acetobacter xylinum menciptakan kondisi anaerob bagi pertumbuhan sel-sel khamir dalam memfermentasi glukosa menjadi alkohol. Selanjutnya alkohol dijadikan substrat bagi aktivitas Acetobacter xylinum untuk menghasikan asam asetat ${ }^{(23)}$. 


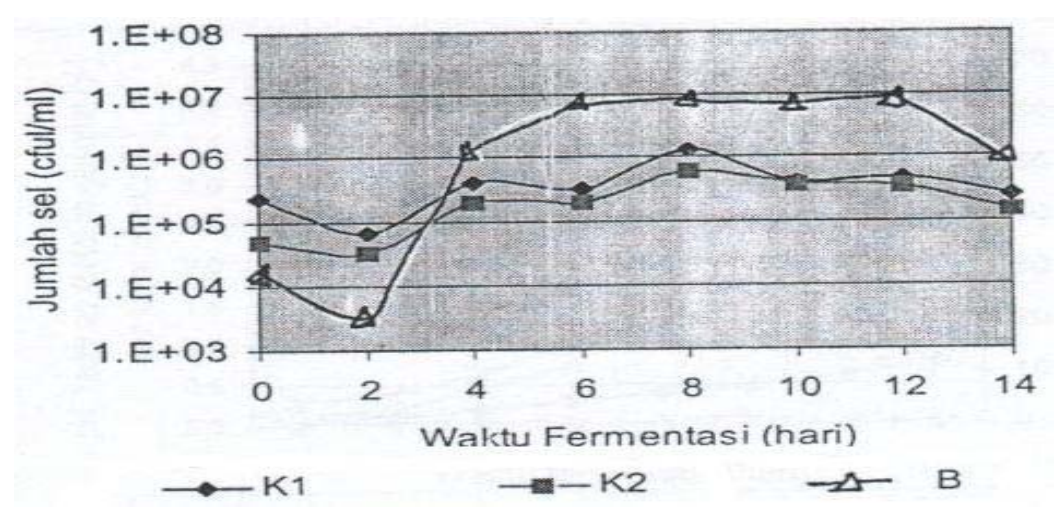

Gambar 7 Pola pertumbuhan kultur campuran mikroorganisme selama fermentasi "Tea-cider".

Keterangan:

$\mathrm{K} 1$ = Schizosaccharomyces pombe, $\mathrm{K} 2=$ Brettanomyces $s p, \mathrm{~B}=$ Acetobacter xylinum.

\section{$5 \quad$ Uji Aktivitas Daya Hambat Bakteri}

Uji aktivitas daya hambat bakteri (anti bakteri) dimaksudkan untuk mengetahui kemampuan produk "Tea-cider" dalam menghambat pertumbuhan beberapa bakteri patogen yang biasa menimbulkan penyakit. Uji kemampuan produk "Tea-cider" dari inokulum alami dan inokulum campuran isolat hasil isolasi dari produk "Tea-cider" umur inkubasi 12 hari dengan kadar asam asetat 0,732\% ("Tea-cider" 1 dari inokulum alami/"starter") dan 0,504\% ("Tea-cider" 2 dari inokulum isolat) dan sebagai kontrol digunakan larutan teh hitam 1\%. Bakteri uji yang digunakan adalah Escherichia coli, Staphylococcus aureus dan Pseudomonas aeruginosa, karena bakteri ini termasuk patogen terhadap manusia, dan sering ditemukan dalam darah ${ }^{(5)}$.

Hasil penelitian menunjukkan adanya penghambatan yang berbeda untuk ketiga bakteri uji (gambar 8). Penghambatan terutama disebabkan oleh kandungan kadar asam asetat yang tinggi dari "Tea-cider". Hal ini dibuktikan oleh penelitian Greenwalt et $a l^{(15)}$, bahwa dengan kadar asam asetat "Tea-cider" sebesar $0,7 \%$ dapat menghambat pertumbuhan beberapa bakteri Gram positif dan Gram negatif, seperti: Bacillus cereus, Salmonella cholerasius serotype typhimurium, Staphylococcus aureus, dan Eschericia coli.

Daya hambat produk fermentasi "Tea-cider" terhadap pertumbuhan Pseudomonas aeruginosa dan Staphylococcus aureus rendah dibandingkan dengan daya hambat terhadap Escherichia coli. Hal ini disebabkan karena 
kedua mikroorganisme tersebut memiliki toleransi terhadap kisaran lingkungan yang luas, kerena memiliki keragaman genetik yang tinggi Staphylococcus aureus memiliki plasmid yang membawa gen untuk kekebalan terhadap senyawa anti bakteri ${ }^{(14)}$, sedangkan Pseudomonas aeruginosa memiliki plasmid yang mengkode enzim pada jalur metabolisme spesifik pada substrat spesifik/khusus, sehingga mampu beradaptasi pada kondisi lingkungan yang ekstrim, seperti pada medium yang cukup asam.

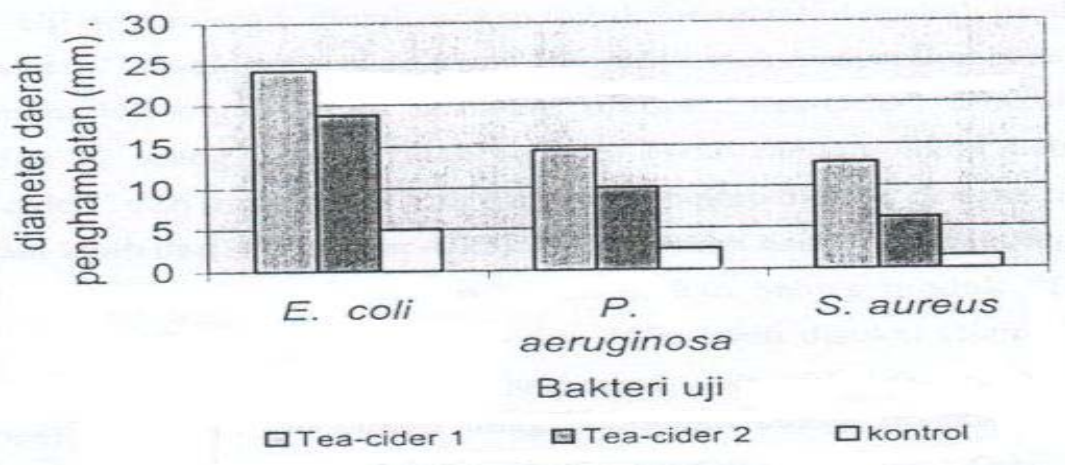

Gambar 8 Hasil uji aktivitas daya hambat bakteri.

Keterangan:

"Tea-cider" 1 = Produk "Tea-cider" dari inokulum alami (starter).

"Tea-cider" 2 = Produk "Tea-cider" dari inokulum campuran isolat.

Kontrol = larutan teh hitam $1 \%$.

\section{$6 \quad$ Uji Organoleptik}

Uji organoleptik dengan metode Hedonik dimaksudkan untuk mengetahui apakah produk fermentasi "Tea-cider" bisa diterima atau tidak oleh masyarakat sebagai minuman ${ }^{(25)}$. Uji organoleptik produk "Tea-cider" dilakukan terhadap 12 orang panelis yang memenuhi persyaratan untuk uji organoleptik dengan metode Hedonik. Hasil menunjukkan bahwa "Tea-cider" dari inokulum awal (kultur alami) cukup disukai dengan nilai rata-rata lebih dari 4 (gambar 9). Hasil uji organoleptik dengan kriteria aroma, rasa, warna menunjukkan bahwa produk "Tea-cider" dengan kadar gula awal $10-15 \%$ lebih disukai. Hal ini disebabkan oleh kandungan gula akhir (glukosa dan fruktosa), masih cukup tinggi sehingga cukup disukai oleh panelis.

Cita rasa produk "Tea-cider" dengan inokulum kultur campuran murni isolat hasil isolasi kurang disukai (gambar 9), karena proses fermentasi dengan kultur campuran isolat murni tersebut belum sempurna. Hal ini diduga disebabkan oleh beberapa mikroorganisme yang tidak terlibat karena tidak terisolasi dalam proses fermentasi tersebut, sebagaimana yang terjadi pada kultur alami. Selain 
itu fermentasi "Tea-cider" dengan menggunakan tiga isolat menyebabkan produk asam-asam organik dan senyawa lainnya tidak selengkap sebagaimana produk metabolit "Tea-cider" dengan menggunakan kultur campuran alami ("starter"). Proses fermentasi yang kurang sempurna ditunjukkan dengan tipisnya sekali pembentukan lapisan "nata" yang terbentuk, yaitu hanya setebal 2-3 mm pada akhir fermentasi. Sedangkan untuk produk fermentasi "Tea-cider" dengan kultur alami menghasilkan lapisan "nata" setebal $12 \mathrm{~mm}$ pada akhir fermentasi.

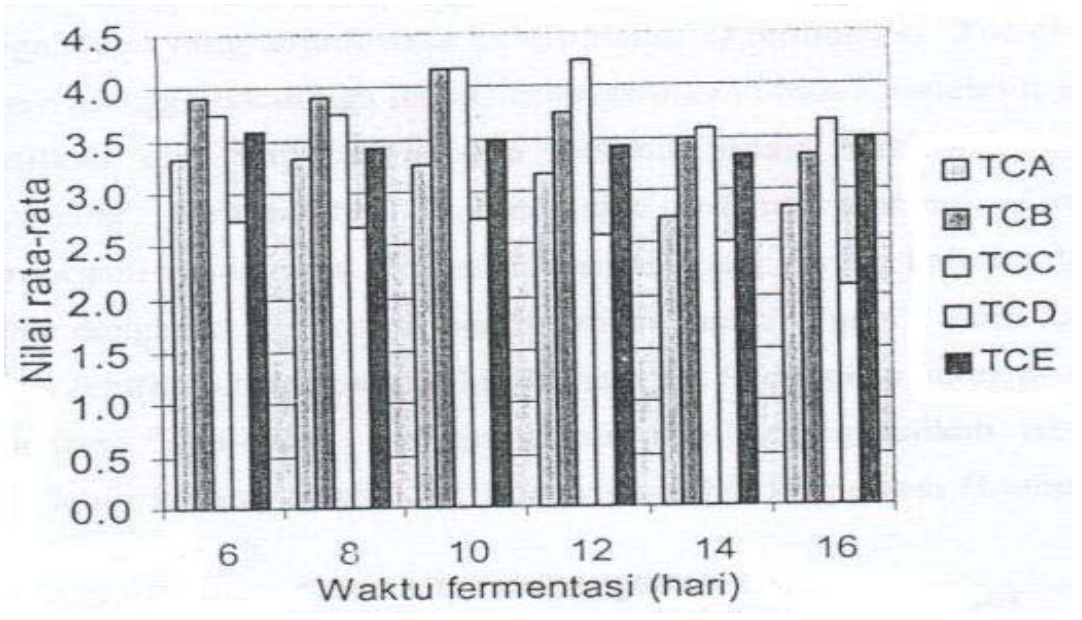

Gambar 9 Hasil uji organoleptik dari 12 orang penalis untuk kriteria rasa.

\section{Keterangan:}

TCA : Produk "Tea-cider" dari teh hitam dengan "starter" 10\% (v/v), kadar sukrosa awal $5 \%(\mathrm{~b} / \mathrm{v})$.

TCB : Produk "Tea-cider" dari teh hitam dengan "starter" 10\% (v/v), kadar sukrosa awal $10 \%(\mathrm{~b} / \mathrm{v})$.

TCC : Produk "Tea-cider" dari teh hitam dengan "starter" 10\% (v/v), kadar sukrosa awal $15 \%(\mathrm{~b} / \mathrm{v})$.

TCD : Produk "Tea-cider" dari teh hitam dengan kadar kultur campuran isolat perbandingan jumlah sel $(\mathrm{B}: \mathrm{K} 1: \mathrm{K} 2)=(5: 1: 1)$, kadar sukrosa awal $10 \%$ $(\mathrm{b} / \mathrm{v})$.

TCE : Produk "Tea-cider" dari teh hijau dengan "starter" 10\% (v/v), kadar sukrosa awal $10 \%(\mathrm{~b} / \mathrm{v})$.

\footnotetext{
Nilai rata-rata

$1=$ tidak disukai

$2=$ kurang disukai

$3=$ cukup disukai

$4=$ disukai

$5=$ sangat disukai
} 
Lamanya fermentasi mempengaruhi cita-rasa produk "Tea-cider", semakin lama waktu fermentasi maka produk "Tea-cider" kurang disukai. Hal ini terjadi karena pembentukan asam semakin lama semakin tinggi, dan menyebabkan $\mathrm{pH}$ cairan "Tea-cider" menurun sampai di bawah 3, sehingga kurang disukai oleh para panelis. Histogram gambar 9 menunjukkan bahwa produk fermentasi "Teacider" terutama dengan kultur campuran "starter", pada hari ke 10 dan ke 12 disukai. Hal ini disebabkan pada hari ke 10 dan ke 12 kandungan asam asetat masih rendah, yaitu untuk TCB $0,4989 \%$ dan TCC $0,462 \%$ pada hari ke 10 , dan TCB $0,582 \%$ dan TCC $0,52 \%$ pada hari ke 12 . Nilai derajat keasaman $(\mathrm{pH})$ masing-masing TCB 3,01 dan TCC 3,03 pada hari ke 10 dan $\mathrm{pH}$ pada hari ke 12 adalah TCB 2,89 dan TCC 2,92. Produk fermentasi "Tea-cider" dengan kondisi kandungan asam asetat dan $\mathrm{pH}$ tersebut, cukup sesuai dengan cita-rasa para panelis.

\section{$7 \quad$ Kesimpulan}

Dari hasil penelitian dapat ditarik beberapa kesimpulan yaitu:

a. Isolat mikroorganisme yang berperan aktif dalam fermentasi "Tea-cider" yang berhasil di isolasi terdiri dari dua jenis khamir (Schizosaccharomyces pombe (K1 dan Brettanomyces $s p$ ) dan bakteri asam asetat (Acetobacter xylinum).

b. Kondisi yang baik untuk pembuatan "Tea-cider" adalah dengan inokulum dari kultur campuran alami ("starter") $10 \%$ (v/v), kadar sukrosa awal 10\% $(\mathrm{b} / \mathrm{v}), \mathrm{pH}$ awal medium 5 dan suhu inkubasi $30^{\circ} \mathrm{C}$.

c. Produk fermentasi "Tea-cider" memiliki daya antimikroba terutama karena kandungan asam asetatnya yang cukup tinggi, terhadap beberapa bakteri patogen, seperti Escherichia coli, Pseudomonas aeruginosa dan, Staphylococcus aureus.

d. Produk fermentasi "Tea-cider" memiliki cita-rasa yang disukai.

\section{Daftar Pustaka}

1. Atlas, R. M., Parks, L. C. (ed), Handbook of Microbiological Media, CRC Press, Inc., Boca Raton Ann Arbor, London, Tokyo, pp. 1011 (1993).

2. Beech, F. W. \& Davenport, R. R., The Role of Yeast in Cider Making, Rose, A. H. \& Harrison, J. S. (ed), The Yeast vol. 3 Technology, Academic Press. London, p. 73-95 (1970).

3. Bisson, L. F. \& Kunkee, R. E., Microbial Interaction During Wine Production. Zeikus, J. G. \& Johnson, E. A. (ed), Mixed Culture in Biotechnology, Mc. Graw-Hill Inc., p. 48-53 (1991). 
4. Buchanan, R. E., \& Gibbons, N. E. (ed), Bergey's Manual of Determinative Bacteriology, Eighth edition, The William \& Wilkins Company, Baltimore, p. 183-186 (1974).

5. Brock, T. D. \& Madigan, M. T., Biology of Microorganisms. Sixth edition. Prentice-Hall International, Inc., pp. 403-405, 469, 472-473, 478479 (1991).

6. Cappucino, J. G. \& Shermann, N., Microbiology: A Laboratory Manual, The Benyamin/Cummings Publishing Company, Inc. California, pp. 7578, 275-276 (1987).

7. Carr, J. G., Methods for Identifying Acetic Acid Bacteria, Gibbs, B. M., \& Shapton, D. A. (ed), Identifications Methods for Microbiologyst, Part B Academic Press, London, p. 1-7 (1970).

8. Cindawati, Penentuan Kondisi Terbaik Produksi Glukosa Cair oleh Aspergillus niger Van Tiegh pada Substrat Serbuk Bongkol Pisang, Skripsi, Institut Teknologi Bandung, hal. 32, 69 (1996).

9. Colome, J. S., Cano, R. J., Kabinski, A. M. \& Grady, D. V., Laboratory Exercises in Microbiology, West Publishing Company, New York, pp. 28-32, 104-105 (1986).

10. Fardiaz, S., Fisiologi Fermentasi, PAU IPB, Bogor, hal. 11-16, $94-99$ (1987).

11. Frazier, W. C. \& Westhoff, D. C., Food Microbiology, Fourth edition, Mc. Graw-Hill, Inc. New York, pp. 323-333, 341-347, 393 (1988).

12. Frank, G. W., Kombucha Healthy Beverage and Natural Remedy from the Far East Its Correct Preparation and Use, Publishing House Ennsthaler Great Britain, pp. 38-43, 64-82, 108-110 (1995).

13. Gonzales, J. G., Coggon, P. \& Sanderson, G. W., Biochemistry of Tea Fermentations, Formation of t-2-Hexanal from Linolenic Acid, Journal of Food Science, Vol., p. 797-798 (1972).

14. Gupte, S., Penerjemah Julius, Mikrobiologi Dasar, Jakarta, hal. 180-181, 282-283, 262-264 (1990).

15. Greenwalt, C. J., Ledforf, R. A. \& Steinkraus, K. H., Determination and Characterization of Antimicrobial Activity of The Fermented Tea Kombucha, Journal Kombucha, www.kombu.de.com, p. 1-4 (1999).

16. Haslam, E., Natural Polyphenols (Vegetable Tannins) as Drugs: Possible Modes of Action, Journal of Natural Product, Vol. 59 no. 2, p. 205-215 (1996).

17. Hesseltine, C. W., Mixed Culture Fermentation An Introduction to Oriental Food Fermentation, Zeikus, J. G. \& Johnson, E. A. (ed), Mixed Culture in Biotechnology, Mc Graw-Hill, Inc. New-York, p. 1-7 (1991).

18. Horwits, W., Official Methods of Analysis of The Association of Official Chemist, Second edition, Benyamin Franklin, pp. 194, 961-964 (1975). 
19. Lodder, The Yeast A Taxonomic Study: Yeast Their Identification Prevation \& Use in Biotechnology, Thailand Institute of Science Life and Technological Research, Bangkok, p. 133-170 (1970).

20. Pryor, B. \& Holst, S., Kombucha Phenomenon The Miracle Health Tea, Second Edition, Sierra Sunrice Books, California, pp. 40-43, 122-123, 129-132 (1995).

21. Roussin, M. R., \& Meibos, R., Analyses of Kombucha Ferments: Report on Growers Preliminary Investigation into the Chemical Constituents Found in the Fermented Beverage Kombucha or Manchuria Mushroom Tea, Information Resources, L. C., www.geodetic.com, p. 1-15 (1996).

22. Salle, A. J., Fundamental Principles of Bacteriology, John Wiley \& Sons, Ins. New York, pp. 308, 394-400 (1954).

23. Sutherland, I. W., Bacterial Exopolysaccharides, Rose, A. H., Tempest, D. W. (ed), Advanced in Microbial Physiology Vol. 8, Academic Press, London, New York, p. 143-203 (1972).

24. Swings, J. \& De Lay, J., The Genera Gluconobacter and Acetobacter. Starr, M. P. et al. (ed), The Prokaryotes vol. II., p. 771-776 (1981).

25. Waluyo, S., Beberapa Anak Tentang Pengelolaan Vinegar, Dewa Ruci Press, Jakarta, hal. 8-15, 27-31 (1984). 